\title{
TEACHERS' PERCEPTION OF LITERACY PROGRAM: IT'S IMPLICATION TO THEIR ATTITUDES AND ACTIONS
}

\author{
Fajar Susanto \\ Universitas PGRI Adi Buana Surabaya \\ fajarsusanto@unipasby.ac.id \\ Irfan Rifai \\ Universitas PGRI Adi Buana Surabaya \\ Irfan.rifai@unipasby.ac.id
}

\begin{abstract}
Teachers as the tip of lance play important roles in the success of the implementation of school literacy program such as possessing positive perception of literacy practices. Recognizing the important roles of teachers in the implementation of literacy program in the schools, this study aims to investigate the teachers' perception toward the implementation of literacy program at a Junior High School in Surabaya. This study is designed as an interpretative qualitative approach. Primary data were obtained through open interviews and observations and supplementary data source included student journal. The data findings showed that teachers have positive perceptions on literacy program. They argue that school literacy program potentially enables to build up the students' good habits. Through the habituation of a thirty-minute reading before the class, it can raise the students' awareness on literacy - reading and writing. Moreover, the school literacy program benefits the students' competency in understanding long texts and can help them to be more critical and creative. In addition, instead of students who take advantageous from the literacy program, teachers are also equally benefited from exposure to daily literacy practices within the school. The teachers tend to follow the rhymes of the literacy practices which are marked by reading and writing activities. In this sense, literacy practices facilitate teachers to develop their practical writing abilities and increase their awareness to be the role model in the classrooms particularly in the literacy practices. This study emphasizes that literacy practices can be double blades, on one side it is beneficial for the students and on another side it is advantageous for the teachers.
\end{abstract}

Keywords: teachers' perception, literacy program, literacy awareness, reading culture

\section{INTRODUCTION}

Teachers given institutionalized authorization in the school (Lundgren et $a l, 2015)$ become crucial for the implementation of the literacy program. The aim of this study is to understand and narrate the teachers' perception of literacy 
program and how their attitudes and actions in carrying out the program. Literacy program in Surabaya becomes strategic policy from local government in which the government has declared Surabaya as literacy city. The success of literacy program cannot be separated from how important teachers in leading and guiding the students to participate actively.

The implementation of literacy program in Junior High School in Surabaya becomes the concern of local government of Surabaya to develop the students' reading awareness. As we know that the reading awareness for the school students in Indonesia becomes a big problem since Indonesian students' performance in reading and writing is categorized as low performance. This fact can be seen from a survey done by Programme for International Students Assessment (PISA) in 2015. The result of the survey conducted by PISA for Indonesian students' performance in reading was categorized as low performance. Indonesian students' rank was in 61 of 69 countries evaluated by PISA. Seeing this indicator of reading awareness of Indonesian students is extremely worried about. What Taufik Ismail criticized the situation as "a tragedy of zero books" (see, Susanto and Rifai, 2017) is the worst tragedy for education in Indonesia because the students only read one book for a year. This tragedy may not continuously occur and this situation makes the next generations left behind from other countries.

Teachers who take the important roles in education have big contribution to the literacy program and in increasing the students' literacy awareness either at school or at home. Reading as social practices (Papen, 2016) must be applied comprehensively in order that reading and writing becomes activities not only for habituating the students in reading and writing but also for improving the students' skills. Literacy practices done by students for their activities in the school need sufficient awareness that reading is a habit. Reading habits cannot be formed as people turn back their hands but habits have to do with actions done continuously. Reading habits can be formed through the students' awareness and awareness can be created through a habituation of their lives and activities.

How important the literacy program for education needs to be taken consideration because through this program there must be essential impact for the students. In this sense, Chiu (2015) asserts "reading and writing are the foundation skills for education and language development" and Paxton and Frith (2014) cited by Chiu (2015) argue that the central process of learning is reading and writing. Although the program gives some benefits for education, teachers and good environment cannot be taken aside from the literacy program at school. It is also asserted by Lundgren, Scheckle and Zinn (2015) that teachers are ones who are given institutionalized authorization in school to support the dominant literacy in school, which has institutional values and norms.

According to Janks (2010), there are four concepts in order that a literacy program can be implemented by teachers in the school, namely access, deconstruction, reconstruction and domination. Access is related to who is given and to the literacy usage and variation and how this can occur. Deconstruction is about the analysis of text types the students identify based on the linguistic characteristics and structures. If the students have this awareness, they will have the possibility to reconstruct their own text. Domination is closely related to who is allowed to write 
Street and Lefstein (2007) state that literacy is important for the cognitive development, communication ability, identity and wider than those are mentioned, it can be used for the strategic tool of nation to increase the economic level. For example, the relationship between social condition, economy and culture towards literacy can be seen from OECD in 2009 in which the average of Europe countries that their social economy are low also showed that their literacy is low. Bulgaria, Romania, and Austria occupied the highest rank for the lowness of test results of PISA (PISA 2009).

A research showed that teachers' perception, knowledge and attitude have a big influence towards the teaching success including the success of teaching literacy. Worthy and Patterson (2001) reported that teachers' positive beliefs to their own abilities and students' abilities really motivate the achievement of learning objective. This argument is similar to Mesmer (2006) in which he said that teachers' perceptions and beliefs indeed influence the success of practices in the class including the practices of teaching literacy. While Hathway and Risko (2013) argued that knowing and believing is so crucial towards the teachers' development either in terms of teaching or implementing the teaching program.

Wang and Kirkpatrick (2015) point out that the institution that gives significant influences to the students' habits is a school. In this sense, school is a place that influences the students doing some activities in relation to reading and writing, in other words, it is literacy practices that form the students having awareness in reading and writing as well as in improving their competences in their study. School is an institution that is designed to employ learning process carried out by the students and these activities certainly will never be separated from reading. That's why school is ideal institution to develop reading culture.

\section{METHOD}

To get a deeper understanding of this study, how the teachers' perception of school literacy program implemented in Junior High School in Surabaya, an interpretive qualitative method was used. The researchers try to illustrate some instances of events in order that the researcher and the readers are familiar with the situation. This study is a case study in which according to de Silva Joyce and Feez (2016: 242), "the information and the data collections are based on the particular participant or a small group". The data were taken in one favorite school in Surabaya in which the school has conducted the literacy program since the Surabaya government declared Surabaya as "Literacy City". Through this school, this study captured how the teachers and students do literacy practices comprehensively especially in relation to capturing the teachers' voices of literacy program that has been conducting for years.

The respondents participating in this research were teachers who have to do directly on literacy program in the school. Three teachers and one student involve in face to face interviews. Besides conducting interview, the researchers also collected secondary data through class observations and artifacts.

The primary data of this study are transcriptions of teachers' interviews and also the student's interview conducted in narrative method. The researcher used open-ended questions in the data collections. Based on the data transcription, the data was analyzed based on the themes emerged from the interviews and secondary data supporting to implementation of the literacy program. 


\section{FINDINGS AND DISCUSSION}

Based on the data found in this study, we can explain that there are four focuses of discussion in terms of the teachers' perception seeing the literacy program conducted in the school. The success of literacy program in the school is always connected with the teachers conducting the program because teachers are the tip of lance in education and they have done great works to the improvements of the students' competencies and behaviors. We have seen that teachers have positive perception seeing to the implementation of literacy program conducting in Junior High School in Surabaya.

To know their positive perception in the implementation of literacy program in school, it can be illustrated through these discussions. The first, the discussion will be presenting the benefits of literacy program towards students' reading culture and awareness. The second will be presenting the influence the literacy program to the improvement of students' reading competency. The third is about the students' achievement. The last section is about teachers' creativities in implementing the literacy program.

\section{Forming the Students' Reading Culture and Awareness}

It is not easy to change the students' behaviors especially to change their habits to read and write. By the implementation of school literacy program, teachers have beliefs that school literacy program can change the students' habits in reading and writing. These positive expectations are teachers' belief towards school literacy program conducted in the school to give positive impacts to the students.

Based on the data found, a teacher argues that reading culture and awareness can be created through this program, that is, the literacy practices for a thirty-minute reading implemented before the lesson begins. The target for the first step the teacher expects is to civilize the students to read.

"That is only reading culture, what we are going to target is, become a culture, like to read, that becomes a culture, not only read but also become to write, that's it, what we are going to make, but once again it needs strong efforts"

The key point from this extract is that reading activity for students is something difficult to do and it needs strong efforts to change their habits. A thirty-minute reading every morning before the lesson starts is an effort to civilize the students like to read. Making the students accustomed to read must be boosted in order that the students gradually have reading awareness. As everyone knows that the reading awareness for students is low performance. Consequently, literacy practices, reading and writing in the school, are something difficult to find in the school activities. Teachers must accompany and incite the students to read in literacy hours.

Habituation of reading for thirty minutes before the lesson starts in the morning will increase the students' awareness, besides they also increase their literacy skills. What is underlined case from the data extracted from the interview is that the problem faced by the teachers is about how the students become more 
enthusiastic to read, and reading becomes their needs so that teachers who lead them in the class do not need to force them to read. See the following extract:

"Because they are still children, if (they are) not monitored in the way a little bit force to the situation, the children tend (not to read), maybe their habits at home. Later is different. At the beginning it hasn't become habituation. Later, our target is that it becomes habituation"

In relation to literacy practices conducting in the school, teachers regard that this program sufficiently help students become more aware and that reading is so important. Teachers regard that cultivating deep reading habits among the students will not happen if there is no habituation for students to read. The students' habit cannot be changed like we turn back our palm of hands. This case can be described from the extract presented below:

"The problem is if the teachers make less effort to lead the student, the students tend not to have reading culture. The reading culture is still not owned by the whole students. Our target is the whole students, but it is a half of students who have good reading culture, I said, but a half of students strongly need incitement from the teachers. It is a challenge for us to create literacy culture and it is a process to be achieved."

In this situation, it can be described that teachers who involved in this program showed that they tried hard to create a situation in order that literacy culture or habituation for students to read can be achieved. If the teachers have no positive perception or they do not support to this literacy program in their school, they will not do anything. Literacy practices are positive activities in that this program can help the students become more interested in reading. The teachers also told that there are significant developments of reading performance because of these practices. The habituation seems to run what teachers expect. There are a lot of influences towards the students' behaviors either in academic activities or non academic activities the students perform.

\section{Improving the Students' Competency in Understanding Text}

Reading and how to understand text is a unity that cannot be separated from reading activities. The students' competency in understanding text needs trainings so that they have ability to understand text comprehensively. Teachers regard that through this program, a thirty-minute reading policy before the class begins can give positive impact to the students. The school students must be led to have strong habit in reading. This view is in accordance with what Staudinger (2017: 2) says "students need powerful reading habits so they are not struggling alone in their dorm rooms or at their kitchen tables".

The students' reading competency must be sharpened because it is the ground and the general skill in order to comprehend kinds of field. If the students do not immediately have reading competency in their early age, the students will have difficulties to learn the lessons in the class (Lerner, 1988). Luckily, the literacy practices have given a significant influence for students, that is, in understanding text. The teachers argued that literacy program convincingly help 
school students increase not only their ability to read but also their competency to understand longer text. It can be illustrated from the following extract:

"Instead teachers support, even Indonesian language teachers. I am an Indonesian language teacher. I love it, because the students' reading competency. Reading interest is still low in Indonesia, so that it has impact to Bahasa Indonesia lesson, because the texts in Bahasa Indonesia lesson are long. So is UNAS, so that with the implementation of literacy program, the students begin to love reading. So when they have a question in long texts, they are not awkward anymore. The students are usually like that. It is different from Math. The question is to the point and only one line, counted then found. Bahasa Indonesia isn't (like Math). (The long texts) must be read many times and must truly understand the texts. By means of the literacy program, then, this program really gives the students benefits and helps them in their lessons, anything."

What has been told in this extract is explicitly stated that literacy program has given big and positive impacts for the school students of junior high school. The literacy program has gradually raised not only their awareness to be fond of reading and but also their comprehension to understand long texts. In this situation, we can say that literacy program has changed the way the school students think and also it has indirectly formed the students' habits to understand longer texts.

Based on this data, it can be explained that through literacy practices have significant impacts to the competency and performance of students in achieving their study to finish. Bertram (2006) clearly states that the students who have low reading and writing competence in state schools in South Africa tend to have negative impact to students' ability to succeed in their academic studies.

\section{Improving the Students' Performance}

The implementation of school literacy program is aimed at civilizing reading and writing for students at all school levels. It can be said that reading and writing culture of the students at all level can be a standard measure of developed education of a country. In the developed countries, reading and writing is common activities for students. But in Indonesia, reading and writing has not been common activities for students. We need process to change this situation. Therefore, these literacy practices must be employed in the school at all levels. In fact, these literacy practices have given some benefits and changes for students' skills not only the habituation as the target but also creativity and achievement.

As explained before that the target of literacy program in the school is the habituation. The target is simple but it is the ground of literacy practice and we need long process to make the students be fond of reading. The habituation becomes the first step taken by teachers in order that the students have awareness about reading, so that reading activities not only happen at school but also happen at home. As Pahl and Rowsell (2005) state that the collaboration amongst teachers and parents has been positive acts in order to achieve a good achievement for students' awareness. When reading is not a compulsion for students, students will 
have joyful activities. Consequently, the students' creativity will emerge with their skills.

What activities do students make? In the beginning of this program, it was told that the habituation is the first target. But then, it gradually links to other things. The literacy program has changed the students in the way they think creative. The literacy practices, reading and writing, turn into activities that the students experience as Pahl and Rowsell (2005) say, "particular practices associated with different domains, that is, spaces in life".

Particular practices, the students performed during the school literacy practices, become the interesting activities for students. Some activities have been carried out in relation to literacy practices. The students become more active and the activities give positive effect toward their cognitive development and also their lives. One of activities of literacy practice, the teacher said, is routinely carried out by students every Wednesday once in two week.

"So, after finishing one book, the students make a resume and the resume is put in the class reading corner. Not only do the students read and write but they also tell a tale. So, what has been read is made the resume, and then conveyed. And the telling a tale not only use Indonesian but also Javanese, Korean and English"

This activity has told us that literacy practices are not only reading and writing but the practices can be different forms and positively give the students new experience done in their lives. The activity is performed thirty minutes in one place that has been prepared called "Creative Corner" in which the students can perform their shows in front of their friends. This practice made the students enjoy the performance and this performance could be a pleasurable activity. The multilingual skills also become the interesting topic for this practice because it can be the arena for students showing their language skills especially in mastery of languages. In addition, the skill of speaking is one activity that can be sharpened through this practice.

The literacy practices can be in different ways, that is, "the diversity of literacy practices - things people do with literacy" (Papen, 2016: 2). There are many things that the students can do with literacy. From the interview we found that some activities have been done in relation to literacy practices.

"Every Saturday, before not in Saturday, but in the lesson hours, that is, we took the students for book tour. So, every class was sent to Balai Pemuda (Balpem). They were taught how to read fast and well, how to make a book. Then, we extend to the Saturday. In Saturday, there is cheerful literacy. We also sent every class"

From this data fragment, it can be enlightened that literacy practices can give the students some activities that are different from what they have got in their school and this activities are not separated from the struggle of the teachers in succeeding the implementation of literacy program. The teachers try to give a different situation so that the students feel happy to learn. 
From this discussion, we can see that the students get some experiences in relation to the literacy practices that are important for their lives. According to Janks (2010), the teachers give the students access to literacy practices to get knowledge and experiences not only the school but also outside the school. He added that how important the teachers are as the facilitators of the students in their participation of literacy practices.

Moreover, the research finding also demonstrates that the students have developed their skill so that they can get a good achievement in term of literacy program. They become autonomous learners from the literacy practices. The students become more independent in doing some activities such as initiating, developing and creating the ways to carry out the literacy practices (Fajar and Irfan, 2017). The students' skills and competence certainly give some benefits to the students themselves. Through this program, a student was told that she has got the champion number 2 in a certain competition in terms of literacy she discussed. The students took the theme in relation to library, in which according to her teachers she like to be in the library every school day.

\section{Boosting the Teachers to be More Creative}

Teachers are elements that hold the important role for the success of implementing the literacy program in the school. Teachers have institutionalized authorization (Lundgren, et.al, 2015) that is useful for the implementation of literacy program in the school. The success of this program is not separated from teachers' struggle and perseverance in implementing the program. The teachers have concrete acts in realizing the program well-running. How to succeed the program is not an easy work because teachers have some duties to be done, such as teaching, educating students and doing their administration. In addition, there are many things they have to sacrifice in these activities such as time and energy. They also work in team in order that the work in relation to literacy program can be done well. Time and extra energy given between their other activities have to be appreciated as the forms of their beliefs and positive perception that the literacy program can give positive impacts to the students for their behaviors and habits.

What makes the teachers important in this literacy practices at school is that how the teachers lead and guide the students to do literacy practices on the literacy hours given to the students for thirty minutes before the class begins. Their guidance and supervision for reading and writing in the class are really needed so that the students really do reading and give their summary as the results of reading activities. The students cannot be left in such bad condition in the class in which they do not make something at all. In other words, the students must do reading and writing instead they learn something in relation to their lesson. Literacy hours are for reading not for studying. The teachers' roles can be described in the following extract:

"So, if the teachers do not directly supervise, settle, and place in the right condition, for instance, right now, it is literacy hour, so it must be used to read, must not be used to study. The children still tend to use literacy hour for studying, because they, in this school, are different from other schools and they like to compete. So among them like to.. 'I have to be successful. 
My test score must be good'. So they stole the time for studying. In a certain time, then the supervision and guidance are needed, and cannot be left as such. Literacy hour is used to read story books given, because it is not time for studying, it is time for reading. This is the habituation that we applied here. So, it is adjusted to the right time because there will be outcome later. There will be outcome from the students' reading activities. If the students used to study in the literacy hours, it means that when they will read, because we still habituate them be fond of reading.

The points of this extract are the first, the teacher creativity in the class in implementing the literacy practices is needed such as how to organize the class, how to choose students the right story books or how to organize and settle the class in order that the students truly do what they have to do in the literacy hours. The second is about the teachers' attitudes and actions when they supervise and guide the students in literacy practices. The teachers really do the job as the form of their positive perception toward this program. Although they do not financially get more from this program, they do well between their crowded activities as a teacher.

To make the students more interested in reading, teachers have to be more creative in order that the implementation of literacy program is not only about reading and writing. It is found that the teachers held some contests and gave rewards to students.

"If (we) let them read, only read, they read only. Then there is no flashback after reading, maybe forget. But if it has been embodied by rewriting in the form of a resume, and even there are also contests of writing story. That is the representation of what they read. The rewards can be a book. That is the reward. We announced the winner of reading corner, for instance. That is the reading corner, the setup how they classify the books, book references until how they list them into the inventory, some items that are scored. After (we) announced the winner of reading corner for this period, it has been a reward. The students would compete, but before taking the score, we announced the evaluation period, maybe from 10 August to 17 August. They prepared their reading corner first. The students usually ask to work together to prepare their reading corners each. We announced after scored. Later, there will be delivery of prize. The prize is a reading book"

From the extract, it can be concluded that to motivate the students and to make them more interested in reading, the teachers have to carry out professionally, give incitement to the students by various and creative ways.

The significant impacts of literacy program at Junior High School in Surabaya are not only the students habituated to read and write but the teachers also get the positive impact from this program. Teachers in this school become more active to read and write because the teachers also become good models for the students. Teachers not only ask students to read and write but they also read and write. This situation has formed a delightful education place for the students and teachers to always read and write. This circumstance is an ideal education that 
the government expects. The following data describe how the teachers in this school implementing the literacy practices for students but teachers also implement the literacy practices.

“This is one form of teachers' participations. There are 4 teachers with their work in literacy practices. It is the Head Master's work. This Mam also made. These are essays and the teachers get more impacts from this literacy program. Teachers become writing. So, not only do the students write and join competition, but the teachers are also the same, they write and join journalistic competition, made an article, then academic paper. This is the Head Master's work. There are teachers writing short stories. It become active to write, tell a tale. Willy-nilly, the teachers have to follow the students' rhythm. It is inconceivable that the students do that but the teachers do not. So, the teachers follow to make essays and articles, sir. So, when we told students, request students to write, it is not only a request, but we also do.

The positive attitudes have been showed by the teachers that literacy program carrying out in their school have given meanings for their creativities. They not only lead guide the students with literacy practices but they also make the literacy practices in their school colorful. Reading and writing, then, become their activity besides their duty to teach. For $21^{\text {st }}$ century, teachers must be creative and productive, not only teaching the students but also doing some writing activities. In $21^{\text {st }}$ century education, teachers must be able to become the role models for students.

What has been showed by teacher in literacy practices, as the form of their responsibility to the literacy program, is part of their participation in succeeding the school literacy program that is mandated to every teacher. Besides reading and writing activities, teachers also make something different for the literacy practice. Narrating is one of activities of literacy practice in the school. This is different form of literacy practice carried out at the school.

"Sometimes, in order not to be monotone, we do variation, the Head Mistress told a tale, teachers, and even students' parents, especially the use of Javanese language in which although the language is used a lot in Java, but the children are difficult to understand especially Kromo Inggil (Javanese Variety)"

This finding showed that literacy practices have given different experiences not only for the students but also for the teachers to do something different. This activity is positive for the teachers and students to maintain the cultural awareness that they have. Telling a tale is one of national cultures that must be preserved and this becomes one activity in the literacy practices. The literacy skills showed in this literacy practice of the school becomes the social and cultural skills acquired. The diversity of literacy practices (Papen, 2016), not only reading and writing, are engaged in by the students and teachers in the school. 


\section{CONCLUSION}

The study indicates that teachers' perception of the literacy practices is essential and beneficial for both the students and teachers for their pedagogical practices. From the discussion presented, it can be illustrated that teachers' positive perception toward the literacy program has brought the activities of the school valuable to develop the students and teachers' skills and competencies. The research findings have indicated that the students have benefited from literacy program for their cognitive and affective development, while teachers with their immense activities can also play pivotal role in managing and implementing literacy program while also obtaining advantages from the program. It can be concluded that the positive perception of literacy program can possibly lead to the positive attitudes and actions in which it can be seen from teachers' commitments and creativities in implementing the literacy program. This study contributes to educational practices in Indonesian' schools in which the positive perceptions of the school personnel significantly facilitate to achieve the school goals and government policy, in this sense to support the success of the literacy program in Indonesia.

\section{REFERENCES}

Bertram, C. (2006). Exploring teachers' reading competences: a South African case study. Open Learning, 21(1):5-18.

Chiu, Hazel. (2015). Contemporary Literacy Concepts and Practices of University Students in English Language Education. International Journal of Arts and Sciences. 08(06): 213-228

de Silva Joyce, Helen and Feez, Suzan. (2016). Exploring Literacies: Theory, Research, and Practice. New York: Palgrave Macmillan.

Hathway, J.I. \& Risko, V. (2013). On Becoming Teachers: Knowing and Believing. In Internasional Handbook of Research on Children's Literacy, Learning and Culture. Hall, K., Cremin, T., Comber, B., Moll, L.C.(Eds). UK: John Wiley \& Sons, Ltd.

Janks, H. (2010). Literacy and power. New York: Routledge.

Lerner, T. C. (1988). Learning Disabilities: Theories, Diagnosis, and Teaching Strategies. Boston: Huoghton Mufflin.

Lundgren, B., Scheckle, E. and Zinn, D. (2015). Teachers' Professional Development: Awareness of Literacy Practices. South African Journal of Education, 35(1); 1-11.

Mesmer, H.E. (2006). Beginning reading materials: A national survei of primary teachers' reported uses and beliefs. Journal of Literacy Research, 38(4):389-425

Pahl, Kate and Rowsell, Jennifer. (2005). Literacy and Education. London: Sage Publications Inc.

Papen, Uta. (2016). Literacy and Education: Policy, practice and public opinion. New York: Rouledge. 
Staudinger, A. (2017). Reading deeply for disciplinary awareness and political judgment. Teaching and Learning Inquiry, 5(1). http://dx.doi.org/10.20343/teachlearninqu.5.1.11

Street, B. \& Lefstein, A. (2007) Literacy; An advanced resource book. London: Routledge.

Susanto, Fajar and Rifai, Irfan (2017). Narrating Literacy Practices at an Urban Secondary School in Surabaya. Jet Adi Buana. 2(2): 189-199

Wang, L and Kirkpatrick, A. (2015). Trilingual Education in Hongkong Primary School: an Overview. Multilingual Education, 5(3), 1-26

Worthy, J. \& Patterson, E. (2001). I can't wait to see Carlos!': Preservice teachers, situated learning and personal relationships with students. Journal of Literacy Research, 33:303-344 